\title{
Medisinsk fødselsregister i forskning og forvaltning
}

\author{
Geir Stene-Larsen \\ Nasjonalt folkehelseinstitutt, Postboks 4404 Nydalen, 0403 Oslo
}

\begin{abstract}
Medisinsk fødselsregister ble opprettet i 1967 som en politisk reaksjon på Thalidomidtragedien. Bruk av medikamentet Thalidomid under graviditet førte til at mer enn ti tusen barn ble født med sterkt forkortede eller forkrøplede armer eller ben. Politisk sett var det et sterkt ønske om å sette i verk et tiltak som kunne forhindre at noe slikt skulle kunne skje igjen.
\end{abstract}

Norge var ikke alene om å opprette en slik institusjon. Samme år ble det innført liknende programmer i SørAmerika og Atlanta, USA, men Norge har fortsatt det eldste befolkningsdekkende fødselsregisteret. Flere land har fulgt etter, og nå samarbeider ca. tretti land om å avdekke eventuelle økninger i forekomsten av medfødte misdannelser. Målet er å oppdage eventuelle skadelige effekter av legemidler og andre miljøfaktorer så tidlig som overhodet mulig.

De nasjonale fødselsregistrene har vist seg å være nyttige overvåkningsverktøy. Vi har ikke hatt nye Thalidomidtragedier siden 1967. Selv om det sikkert langt på vei skyldes at legemiddelindustrien ikke lenger markedsfører sine nye medikamenter ovenfor gravide, er det liten tvil om at overvåkningen har vært viktig.

Fødselsregistrene har avdekket en rekke skadelige effekter av medikamenter. Det ble for eksempel påvist at barn av kvinner som måtte bruke fenobarbital og fenytoin hadde økt risiko for å utvikle leppeganespalte. Og da valproinsyre ble introdusert $i$ epilepsibehandlingen, kunne fødselsregisteret påvise at forekomsten av ryggmargsbrokk økte.

Fødselsregistrene har imidlertid vist seg å få betydning langt ut over det å overvåke skadelige effekter av legemidler. I Norge har fødselsregisteret fått en solid plass $\mathrm{i}$ det generelle arbeidet for å redusere dødelighet og sykelighet blant barn og spedbarn. Et av de mest kjente eksemplene er arbeidet for å redusere forekomsten av krybbedød. Fødselsregisteret kunne påvise at helsetjenestens råd om å legge spedbarn på magen for å sove førte til sterk økning i antallet tilfeller av krybbedød.

En annen viktig oppgave for registeret har vært å etterprøve mistanker som pasienter, pårørende eller helsepersonell har fått om skadelig påvirkning i deres miljø. Når det oppstår flere tilfeller av samme tilstand på samme tid eller sted - såkalte klynger - er det naturlig å lete etter en årsakssammenheng. For den det gjelder kan denne sammenhengen føles så innlysende at det kan være vanskelig å godta en forklaring om at det dreier seg om tilfeldige sammenfall. Da er analyser $i$ et register gjerne eneste måten å avklare problemstillingen på.

Etter hvert som vi får stadig bedre oversikt over ulike forhold i samfunnet og hos den enkelte, samtidig som folk flest blir høyere utdannet og bedre informert, blir det stadig større sjanser for at det skal oppstå mistanke om klynger av ulike helseutfall. Derfor får utredning av slike problemstillinger stadig større betydning, og det stilles større krav til registerets kvalitet.

Utredning av et klyngefenomen kan være forholdsvis enkelt, men kan også kreve omfattende forskning. Derfor er det ikke hensiktsmessig å skille overvåkningsfunksjonen fra forskningen. Som oftest foregår overvåkning og forskning helt integrert som to sider av samme sak. Etter Tsjernobylkatastrofen kunne registeret nokså raskt gjøre gode studier som viste at nedfallet i Norge antagelig ikke har hatt effekter på nyfødte barns helse.

Det er viktig å kunne finne årsaker til helseproblemer for om mulig å kunne fjerne disse. Men det er også viktig å kunne fjerne ubegrunnet bekymring. Medisinsk fødselsregister har vært brukt til en rekke studier av mulige helseeffekter av miljøforhold, fra vannkvalitet til høyspentledninger, og fra arbeid i landbruk til arbeid i luftfart. Slik forskning trenger god informasjon om yrkes- og miljøforhold for å ha verdi. De fleste av disse studiene har vært negative, det vil si at de ikke har påvist noen årsakssammenheng, og det er betryggende.

Det er særlig to forhold som har satt det norske fødselsregisteret i særstilling i det internasjonale forskningsmiljøet. Det ene er datakvaliteten; registeret har 100 prosent oppslutning og det inneholder generelt nøyaktige og etterrettelige informasjoner. Det andre er koblingsmulighetene internt og til andre registre.

Det har vært velkjent at mødre med problematiske svangerskap, har en økt sjanse for gjentakelse av problemene. De interne koblingsmulighetene i Medisinsk fødselsregister har fremskaffet unik kunnskap om risiko for gjentakelse av en rekke tilstander, fra perinatal død og medfødte misdannelser til morkakeløsning og svangerskapsforgiftning. Dette er informasjon som er viktig både for foreldre og for de som skal behandle gravide.

Ved at registeret nå har eksistert i 40 år er det også mulig å følge en hel generasjon norske nyfødte fra 60 og 70-tallet for å undersøke hvilke helseutfall som overføres fra en generasjon til den neste. Registeret har for eksempel vist at de aller fleste barn som ble født med en misdannelse, selv blir foreldre. Deres barn har økt risiko for å få den samme type misdannelse som 
mor eller far hadde, men de har ingen økt risiko for å få noen annen type misdannelse. Samlet sett bidrar gjentakelser av en misdannelse fra mor eller far helt ubetydelig til forekomsten av misdannelser blant nyfødte.

Familiegjentakelse kan også gi viktig informasjon om årsaker. Data fra fødselsregisteret har for eksempel påvist at årsaken til svangerskapsforgiftning like mye er å finne $\mathrm{i}$ fosterets gener som i mors egne gener.

Fødselsregisteret har vært koblet mot data både fra Dødsårsaksregisteret, Personregisteret og Kreftregisteret. Med godkjennelse fra Datatilsynet er det også mulig å koble data fra fødselsregisteret med data fra helseundersøkelser og andre forskningsprosjekter. Samlet gir dette unike forskningsmuligheter som har vært godt utnyttet i studier av hvilken betydning kroniske sykdommer hos mor, som for eksempel astma, psykiske lidelser, epilepsi, diabetes, leddgikt eller tuberkulose, har for barnets helse.

Forskningsresultatene fra fødselsregisteret har hatt stor betydning for det store forbedringsarbeidet som har foregått i svangerskaps- og fødselsomsorgen. Tall fra fødselsregisteret har gjort det mulig å vurdere hvilken effekt ulike tiltak har hatt og har gitt grunnlag for å lage hypoteser om hvilke typer tiltak som kunne tenkes å ha effekt.

Fremover må vi forvente at samfunnet vil stille stadig høyere krav til epidemiologisk overvåkning. Derfor må også virksomheten i fødselsregisteret kontinuerlig forbedres og videreutvikles. Norge er blant landene $\mathrm{i}$ verden med lavest spedbarnsdødelighet. Likevel må vi arbeide for at den skal bli enda lavere.

Men selv om dødeligheten er lav rammes mange fødende og nyfødte av helseproblemer. Disse helseproblemene får ofte konsekvenser gjennom et helt liv. Mye tyder også på at grunnlaget for en rekke av våre store folkesykdommer som hjerte-karsykdom, kreft og diabetes legges tidlig, enten i fosterstadiet eller i småbarnsperioden.

Dette er problemstillinger som epidemiologisk forskning knyttet til fødselsregisteret vil bli et viktig hjelpemiddel for å avklare. Dermed har fødselsregisteret etablert seg som en viktig del av helseforvaltningen og forskningssystemet $\mathrm{i}$ Norge og et av våre store forskningsfortrinn internasjonalt. 